УДК 821.161.1-31 Булгаков М.

821.163.41-31.09 Пекић Б.

821.134.3-31.09 Сарамаго Ж.

https://doi.org/10.18485/godisnjak.2021.16.14

Александра Н. Петровић

Универзитет у Београду

Филолошки факултет, докторанд
Оригинални научни рад

Примљен: 20. 09. 2021.

Прихваћен: 05. 11. 2021.

\title{
НОВА ЈЕВАНЪЕЉА И ОТПОР РЕПРЕСИЈИ: МАЈСТОР И МАРГАРИТА М. БУЛГАКОВА, ВРЕМЕ ЧУДА \\ Б. ПЕКИЋА И ЈЕВАНЪЕЉЕ ПО ИСУСУ ХРИСТУ Ж. САРАМАГА
}

Рад се бави испитивањем односа романа Мајстор и Маргарита М. Булгакова, Време чуда Б. Пекића и Јеванђеље по Исусу Христу Ж. Сарамага према библијско-јеванђеоском предлошку, тј. утврђивањем начина на који се јеванђеоски предложак прихвата, одбацује и(ли) ресемантизује са модерног становишта. Испитује се и однос који ликови уметничког света самих романа заузимају према тексту, што отвара питање о односу текста и стварности уопште. Показаћемо како сами романи, при свему наведеном, постају нова, двадесетовековна јеванђеља, са новом-старом причом о отпору репресији.

Кључне речи: јеванђеље, двадесети век, репресија, текст, стварност.

Тоталитарна стварност непосредно је, током прошлог века, утицала на Михаила Булгакова, Борислава Пекића и Жозеа Сарамага, због чега тројица аутора деле готово идентична животна и професионална искуства. Булгаков је живео под Стаљиновом влашћу, када су његове представе биле забрањиване, а он сам тражио прогон из земље (Деветаковић 2004: 165-166). Пекић је због свог политичког ангажовања у Југославији осуђен

*alek.petrov97@gmail.com 
и ухапшен (Пекић 1987). ${ }^{1}$ Пре него што ће отпутовати у Лондон одузет му је пасош и тек касније успева да се тамо пресели (Пекић 1989). ${ }^{2}$ Након тога имаће проблема и са објављивањем књига у Југославији (исто). ${ }^{3}$ Југословенски тип комунизма и стаљинизам Пекић је сматрао „тоталитарним левим доктринама”, како истиче у интервјуу у којем је, између осталог, говорио о Времену чуда (Pekić 1984). ${ }^{4}$ Сарамаго је пак живео под диктатуром португалског властодршца Антонија Салазара, која је, делом, утицала на његово стваралаштво (Salzani C. - Kristof K. P. Vanhoutte 2018: 6-7). Салазаров режим био је режим „чији је захтев за послушношћу и униформношћу мишљења, понашања и идентитета ишао руку под руку са виктимизацијом и прогоном мањина, империјалистичком експлоатацијом, репресивним државним апаратом, цензуром, надзором" (Rollason 2006: 11; према нашем преводу). Многе од ових одлика могу се приписати јудео-хришћанском богу из Сарамаговог Јеванђељ $а$, због чега проучаваоци виде у њему призивање култа диктаторског вође салазаревског типа (исто). Осим тога, конзервативна португалска власт успела је да спречи Сарамагово учешће у избору за Европску награду за књижевност (исто, 3). Сарамаго је касније тај акт окарактерисао као акт цензуре, „достојан фашистичке диктатуре" (исто; према нашем преводу). Тај догађај нагнаће га да емигрира на шпанско острво Ланзарот (исто). Сарамаго је, осим тога, веровао да је и процес глобализације тоталитарног карактера (Rollason 2004: 2). Сматрао је да је „глобализација” „дотрајали еуфемизам за економску и политичку моћ међународног капитала" (исто; према нашем преводу), наводећи да су мултинационалне и трансконтиненталне компаније оне које заиста управљају светом (исто). Осим њих, и медији, штампа и телевизија, како то у једном интервјуу објашњава Сарамаго, отуђују људе и чине их индиферентним према есецијалним питањима (Saramago 2002; према нашем преводу). ${ }^{5}$ Такав приказ модерног глобалистичког света Сарамаго је дао у свом роману Пећина, говорећи да не би желео да роман буде схваћен као одбрана традиционалног начина живљења (исто). ${ }^{6} \mathrm{Ha}$ глобалистичке тенденције ће се осврнути и у Јеванђељу, нарочито у оном

${ }^{1}$ Део интервјуа доступан на: www.borislavpekic.com/p/bio.html [приступљено: 5. новембра 2021].

2 Део интервјуа доступан на: www.borislavpekic.com/p/bio.html [приступљено: 5. новембра 2021].

${ }^{3}$ Исто.

${ }^{4}$ Доступно на: http://www.borislavpekic.com/2008/03/vreme-rei-xd-deo.html [приступљено: 5. новембра 2021].

${ }_{5}^{5}$ Доступно на: https://www.youtube.com/watch?v=jxy_Ax71JUI [приступљено: 5. новембра 2021], од 26.45 до 27.55.

${ }^{6}$ Исто, од 19.00 до 19.50 . 
делу у коме сам ђаво живи „традиционалним” начином живота, не експлоатишући своје стадо оваца и не користећи новац (Saramago 2012: 196).

Три романа којима се бавимо - Мајстора и Маргариту (1966/7), Време чуда (1965) и Јеванђеље по Исусу Христу (1991) - повезује уметнички уобличена критика двадесетовековних репресивних система, те употреба библијско-јеванђеоског предлошка према коме се писци, како ћемо у наставку рада видети, двоструко односе: они прихватају позицију отпора моћи коју нуде јеванђеља, те историјски контекст отпора у којима су јеванђеља настала, прихватајући такође и у њима прокламоване хумане вредности. Са друге стране, писци јеванђеоски текст одбацују или му се изругују са, начелно идентичне, (пост)модернистичке позиције, отварајући притом питања о односу текста и стварности. Тако се, на пример, Време чуда, најраније Пекићево дело, убраја у корпус дела која наговештавају особености нове, постмодернистичке поетике: „нови обликовни поступци уместо представљања слике света нуде испитивање поетичког знања, уместо стварности нуде текстуалност, уместо искуства документ..." (Јерков 1992а: 17). У овом роману поставља се и питање о моћи коју текст и тумачење истог имају над стварношћу, а у вези са Јудиним настојањима да стварност саобрази тексту, у чему поједини проучаваоци виде и зачетак проблематике „виртуалне стварности, губитка значења света, и то услед увишестручених смислова...” (Ахметагић 2006: 36). Демитологизација јеванђеоског текста, иронија, пародија и сатира основна су оруђа писаца који сумњају у визије о будућности света, спасењу човека и тачки врхунца у историји са које ће све претходне патње бити оправдане.

Истраживања сведоче (Horsley 2006: 1209-1212) о томе да први јеванђеоски текстови, попут Јеванђеља по Марку (око 70. г.) или Извора изрека, у науци означеног словом $\mathrm{Q},{ }^{8}$ представљају Исуса као предводника једног од, у оно време, широко распрострањених месијанских и пророчких покрета (исто, 1205) заинтересованих за одбрану Израела од јерусалимских и римских власти. Свакако, Исус ни у једном од романа којима се бавимо није дат у тој улози. Он је код Булгакова мирни филозоф, који позива на симболично рушење храма. Међутим, историјски контекст побуна против власти ипак је видиљив, на пример, у разговору првосвештеника и Пилата у другом поглављу Булгаковљевог романа (Булгаков 2014:

${ }^{7}$ Булгаковљева књига је тада први пут штампана, са цензорским интервенцијама. Рад на роману Булгаков је започео још давне 1928. г. (Деветаковић 2004: 165-167).

${ }^{8} \mathrm{Q}$ је био извор (нем. quelle) речи Исусове (грч. $\lambda$ о́ $\left.1 \alpha\right)$, одакле и назив Logienquelle (Драгутиновић 2010: 167-168). 
$65)^{9}$, као и у Пилатовом поверавању начелнику тајне полиције Афранију (исто, 357). ${ }^{10}$ Сарамагов Исус такође неће бити ни на који сличан начин ангажован, али ће зато недужни Јосиф страдати, неправедно оптужен да је учествовао у побуни против Рима организованој од стране Јуде Галилејца (Saramago 2012: 119). Пекићев пак Исус крајње је морално проблематична фигура, незаинтересована за последице сопственог деструктивног деловања на људе који су предмет његових чуда. Међутим, оно што је важно јесте то што нам се чини да се употребом јеванђеоског предлошка који у себи садржи историјски контекст Исусовог времена призива позиција отпора која би онда имала да буде паралелна са позицијом отпора које уметнички свет целине романа заузима спрам модерних диктатура.

Јеванђеље се у контексту отпора злоупотреби човека у савременим репресивним системима употребљава и онда када се у романима упућује на оне хумане вредности које су у њему прокламоване и углавном везане за личност Исуса Христа. Више пута у Булгаковљевом роману, на пример, сам ђаво, Воланд, говори о милосрђу. Московска публика у Варијетеу одлучује да опрости Бенгалском, којем је Воландова свита откинула главу, након чега Воланд закључује: „људи као људи... Воле новац, али, то је увек и било тако... [...]. Но, лакомислени су... па шта се ту може... и милосрђе понекад заструји њиховим срцима" (Булгаков 2014: 161). Маргарита после бала неће тражити од Воланда да избави Мајстора, већ ће тражити помоћ за измучену Фриду коју је упознала тек пре неког времена (исто, 319). Опет ће то за Воланда бити знак милосрђа које се некад „потпуно неочекивано и подмукло, провуче и кроз најужу пукотину” (исто, 334). По свом човекољубивом сензибилитету Булгаковљев Јешуа нимало се не разликује од јеванђеоског Исуса - он је онај који „љуби непријатеље своје” (Мат. 5:44) и верује да су сви људи добри. Да би показао снагу опроштаја, Јешуа говори Пилату како се суђење у Јерусалиму заправо никад није ни догодило (Булгаков 2014: 456). О милости и опроштају говориће јеванђеоски Исус: „Будите, дакле, милостиви као и отац Ваш што је милостив. / [...]; опраштајте, и опростиће вам се" (Лука 6: 36-37), саветујући притом фарисеје да науче шта значи „Милост хоћу” (Мат. 9: 13 и 12: 7). Управо апостоли у Пекићевом роману упозоравају Јуду „да се није сећао да чини милост" (Pekić 2019: 328). Мада крајње ироничан

\footnotetext{
${ }^{9}$ Првосвештеник се плаши да ће Јешуа подстаћи народ на побуну против Рима. Јудејска елита била је одана Риму јер су њене позиције моћи и привилегије зависиле управо од Римљана (Horsley 2006: 1207), због чега и страх од народних побуна.

${ }^{10}$ Пилат ће у Булгаковљевом роману рећи: „Колико нас је откоштао само тај један месија кога су одједном почели да очекују ове године! Свакога тренутка само то и радиш - очекујеш да будеш сведок најужаснијег крвопролића".
} 
и пародијски, Пекићев роман имплицира постојање система вредности и, ако се руглу извргавају оне наказне, писац несумњиво сугерише какве вредности би требало да постоје. Приказујући Исуса као неемпатичног, човека равнодушног према туђој патњи, осветољубивог и, на крају, лажног и окрутног чудотворца, Пекићев роман призива личност јеванђеоског Исуса и оно што он представља - емпатију и разумевање пре свега, као и чудотворно деловање које је из љубави и милости. Када Петар на почетку Времена чуда у својој посланици тврди да се „неће више поновити да невини одговори кривцу: данас ћеш бити са мном у рају" (исто, 19), Пекићев роман се тиме ослања на јеванђеоски догађај (Лука 23: 43) указујући на изостанак великодушности опроштаја. Становници Старог Јабнела пак бацају на Еглу први камен: „Тек кад први камен, бачен несигурном руком богаља или нејаког детета, тресну поред жене, она се обрати руљи...” (Pekić 2019: 84). На познатом месту из Јеванђеља по Јовану Исус ће спречити каменовање прељубнице: „Који је међу вама без гријеха нека први баци камен на њу”, (Јован 8: 7; наше подвлачење). Сарамагов Исус такође је племенита фигура. Његова дирљива хуманост најбоље се види у плачу над неправедно убијеном витлејемском децом: „О, недужни, недужни, грцао je, изгледа немогуће да је један дечак од само тринаест година, узраст у којем је себичност лако објаснити и оправдати, у тој мери потресен вешћу која не би, према ономе што знамо о данашњем свету, нимало узбудила велику већину људи" (Saramago 2012: 159). Однос између њега и Јосифа биће дирљив однос пун питања о судбини и кривици, о могућности да се опрости другоме, нарочито своме ближњем, и да се пронађе утеха. Занимљиво је да Сарамаго, толико критичан према хришћанству и религији уопште, ${ }^{11}$ поштеђује Исуса било какве критике, супротстављајући његову и Јосифову измењену јеванђеоску причу тиранији.

Тим порукама писци додају и сопствене визије које осмишљавају човекову егзистенцију у, чини се, одувек идентичном, тоталитарном устројству света. Врхунска вредност у Булгаковљевој књизи јесте уметност, њено свезнање и неуништивност. Пишући о односу између Марије Магдалене и Исуса, Сарамаго пак вреднује телесну љубав путем које се тек може доћи до Бога: „Ниси нико ако не волиш себе самога и никада нећеш досегнути Бога ако прво не доспеш до сопственог тела" (Saramago

${ }^{11}$ Док се у Јеванђељу по Исусу Христу концентрише на Нови завет, у свом роману Каин (Saramago 2014) Сарамаго деконструише старозаветне митове - о постанку, дрвету сазнања, првом убиству, Авраму и Исаку, Нојевој барци, Јову итд. - приказујући старозаветног бога као окрутног тиранина који је у првом реду крв што је Авељ убијен. Каин у роману говори богу: „Просто и једноставно, убио сам Авеља пошто нисам могао да убијем тебе” (исто, 34 ). 
2012: 233). Описујући три Марије које пате поред крста због смрти вољеног бића, Сарамаго показује како у његовом јеванђељу „у коме нема јеванђеља, нема благе вести [...] оно што остаје јесу само три Марије са њиховом добротом и сломљеним срцима" (Salzani C. - Kristof K. P. Vanhoutte 2018: 160; према нашем преводу). Женска, људска, „обична”, земаљска љубав остаје код Сарамага непобитна чињеница.

Односећи се на овај начин према јеванђељу, призивајући историјски контекст отпора репресивној моћи и прокламујући наде и визије које се таквој моћи супротстављају, три романа којима се бавимо заправо чине оно што су чинили јеванђеоски текстови, постајући тако нова, двадестовековна јеванђеља, са новом-старом причом о тиранији и отпору. Поред поменутих, постоји много експлицитнијих сугестија да три романа настоје да постану јеванђеоски текст. Сарамаго својој књизи даје управо назив Јеванђеље по Исусу Христу, а не би било погрешно ни назвати га Јеванђељем по Сарамагу, као што поједини проучаваоци зову Булгаковљеву књигу Јеванђељем по Булгакову (Flaker 1993: 427) а он ју је сам у првобитној редакцији назвао Јеванђеље по Воланду (исто, 426). Раван јерусалимских дешавања у Мајстору и Маргарити се још може назвати и Јеванђељем по Пилату. Пекићева књига, или барем један њен део („Смрт на Хиному”), својеврсно је Јеванђеље по Јуди. Занимљиво је осврнути се на то које личности писци бирају за главне јунаке својих јеванђеља. Воланд је једна од главних личности Булгаковљевог романа у којем је представљен као сила равноправна божјој. Он је у Мајстору и Маргарити део силе која „вечито твори добро” (Булгаков 2014: 31), како је назначено у мотоу романа преузетом из Гетеовог Фауста. Када је пред крај романа одлучена судбина Мајстора и Маргарите, тј. када Леви Матеј долази Воланду, он му не каже да је Бог тражио или да му је рекао или да је наредио да одведе Мајстора и Маргариту у спокој, већ каже: „-- Он је прочитао мајсторово дело [...] и моли те да узмеш мајстора са собом и наградиш га спокојем...” (исто, 419; наше подвлачење), чиме се опет сугерише апсолутна једнакост божанског и ђаволског принципа. Ђаво ће бити позитивна и побуњеничка сила и у Сарамаговом роману - модерни писци, чини се, из библијског ђаволовог греха извлаче највеличанственије позитивне потенцијале. Јер, ђаволова побуна састоји се у преиспитивању актуелног поретка, те је Воландова фигура изабрана, тј. Јеванђеље по Воланду је написано да би се преиспитао актуелни совјетски поредак, али и ток историје и људска природа уопште. Пилат је пак главна личност Мајстореве књиге, својеврсног Јеванђеља по Пилату, са којим се такође отвара питање о природи власти, избора између добра и зла, о кривици и 
одговорности, могућности да се опрости себи и другима. Јуда је, затим, једна од најзнаменитијих личности Пекићевог романа. Поједини проучаваоци сведоче како је представљање Јуде као спаситеља света у Времену чуд $a$ у складу са схватањима антиномијске струје у гностицизму која су одбацивала створени свет као творевину демијурга, изједначавајући Јахвеа - који је тај свет створио - са демијургом и одбацујући целокупни старозаветни поредак (Радуловић 2016: 62). У складу са тим, ова гностичка струја поштовала је библијске ликове који су важили за злочинце - попут Јуде или Каина ${ }^{12}$ (исто, 62). Јуда је у Пекићевом роману тип тоталитарног идеолога, површног и невештог тумача Писма, који веру планира и материјализује, жртвовавши јој, као таквој, невине људе. У Сарамаговом роману, на крају, важно место заузима Исусов земаљски отац, Јосиф. Прича о Јосифу на кога пада кривица за смрт недужне витлејемске деце послужила је Сарамагу да уобличи причу о богу-тиранину који сопствену кривицу сваљује на обичне и поприлично немоћне људе, не искористивши моћ коју поседује да спасе оне које може спасти, тј., у овом случају, витлејемску децу. Штавише, рећи ће Сарамаго-јеванђелиста, бог не само да није спасао децу, управо он је њихову смрт наредио, што је грех који му се не може опростити (Saramago 2012: 112). Критика манипулације кривицом, те јудео-хришћанског концепта наследне кривице, којима се алудира на савремене идеологије, кључна је за Сарамагов роман и у том је смислу Јосифова личност у роману подједнако важна као Исусова.

Већ наслови књига и избор главних јунака сведоче о тома да двадесетовековна јеванђеља нису „правоверна” јеванђеља. Говорећи о Пекићевој књизи, проучаваци је називају апокрифним јеванђељем (Ахметагић 2006: $15)$ или говоре о Пекићевој јеретичкој стваралачкој позицији и обликовању јеретичке духовности (Пијановић 1991: 26-27). Дакле, осим што се према јеванђеоском предлошку три писца односе позитивно, ослањајући се на позицију отпора и јеванђеоске вредности, они пишу и сопствена апокрифна, јеретичка и(ли) анти-јеванђеља у којима се јеванђеоски предложак ресемантизује, демитологизује, пародира и одбацује.

У сва три романа јеванђеоски текст је, дакле, демитологизован. Сва тројица аутора служе се „низом реалистичких поступака, који су у функцији веродостојности, конкретизације библијске приче" (Деветаковић 2004: 180). Па чак и оно што се може сматрати елементом фантастике - Исусова чуда - бива или реалистички мотивисано или испародирано.

12 Занимљиво је истаћи како је у поменутом Сарамаговом роману Каин (Saramago 2014) Каин такође уважен као личност која се супротставља старозаветном богу-тиранину демистификујући читав старозаветни поредак. 
Тако, на пример, у Мајстору и Маргарити, Јешуа наизглед „магично” отклања Пилатову главобољу. Ради се, међутим, о томе да је Пилат у роману описан као човек који је изгубио веру у људе и који презире Јерусалим (Булгаков 2014: 357) и, разговарајући са Јешуом, он коначно пред собом има човека који га разуме и емпатише са њим. Нестанак главобоље јесте управо последица чина људске блискости која је у разумевању, љубазности и емпатији. То је „чудо” које се овде заправо одвија. Пекићев и Сарамагов Исус заправо чине чуда - али у оба случаја су та чуда бескорисна и наметнута Исусу: код Пекића она су сведена на своју застрашујућу супротност, а код Сарамага, мада не штете људима, она ипак не мењају ништа и не елиминишу зло (Saramago 2012: 306 и 310). ${ }^{13}$ У сва три романа Исус је представљен као сасвим обичан човек: Булгаковљев Јешуа се не сећа својих родитеља, мада су му причали да му је „отац био Сиријац...” (Булгаков 2014: 49), а Сарамагов Исус је исључиво син Марије и Јосифа. У Времену чуда духовито је, и са сасвим реалистичке тачке гледишта, одбачена могућност о Исусу-месији. Наиме, један колар из Јерусалима пита Јуду о томе ко је уопште тај Исус Галилејац (Pekić 2019: 299). Када Јуда одговори да је то син краља Давида, колар инсистира на томе да га Јуда прави будалом: „Та Давид је живео пре десет столећа! Како му овај тридесетогодишњи јуноша може бити син?” (исто, 300).

И док је реалистички поступак везан за јеванђеоски предложак, фантастика је, на пример, у Булгаковљевом роману везана искључиво за Москву. Исто тако, Пекић је „временом чуда” заправо називао своје време. Са једне стране се, дакле, јеванђеоска прича демитологизује да би се ука-

\footnotetext{
${ }^{13}$ Постоји много сличности између Пекићевог и Сарамаговог романа у погледу третирања феномена чудотворста. Чуда се у овим романима не чине из љубави према човеку и нису показатељ божјег милосрђа. Она губе „унутрашњи, религијски смисао повезивања са Богом” (Јерков 1992b: 1705), а смисао Христове појаве престаје бити ,делатно присуство божје воље, и још важније - љубави, у свету" (исто, 1708). У Сарамаговом роману Исус невољно чини чуда само да би се божји хегемонијски планови остварили (Saramago 2012: 316-344). Његова чуда, као што је речено, не штете људима, али Исус дубоко сумња у њихову сврховитост: он ће, на пример, рећи како је излечење Легиона било попут „орања мора” јер су демони који су изашли из Легиона сада на слободи, још увек постоје у свету и ни сам бог их не може убити (исто, 310). У Пекићевом роману Исус такође невољно чини чуда да би се остварили Јудини планови. Мотивација за чињење чуда је, дакле, изопачена, па су и последице чудотворног деловања трагичне. И Пекић и Сарамаго доводе у питање моралну оправданост чуда васкрсења, сугеришући страхоте двоструког, тј. вишеструког умирања (Pekić 2019: 241; Saramago 2012: 374). У оба романа исмејано је као лажно и чудо у Кани (Pekić 2019: 29-30; Saramago 2012: 301-302). Са друге стране, чудотворно деловање у Булгаковљевом роману не припада Јешуи, већ Воланду и његовој свити. Воландова „чуда”, међутим, немају изопачену мотивацију; она служе да би се казнили криви и боље спознао човек, а Воланд је, осим тога, „део силе која [...] твори добро" (Булгаков 2014: 31).
} 
зало управо на склоност актуелних система да митологизују и прошлост и будућност, стварајући приче о напретку и будућности човечанства, те да би се показала нефункционалност и, што је још важније, злоупотреба таквих прича; са друге стране - савременост је фантастична, пуна чуда. Код Булгакова она је таква јер јој је фалило маште у времену у коме влада строги социјалистички реализам, у коме треба вратити лепоту веровања у надстварно. Међутим, и код Булгакова и код Пекића савременост је чудесна и зато што она даје безброј незамисливих могућности за злоупотребу човека - она је чудесна, тј. нелогична и непојмљива, јер наноси зло људима док им (наводно) помаже.

Не само да се јевађеоски текст демитологизује, он се у овим делима експлицитно одбацује. У другом поглављу Majcmора и Mаргарите, разговарајући са Пилатом, Јешуа истиче како Леви Матеј стално хода за њим и записује без престанка: „Али једном сам завирио у тај пергамент и ужаснуо се. Ама баш ништа од онога што је тамо записано ја нисам говорио. Молио сам га: тако ти Бога, спали тај свој пергамент! Али ми га он истрже из руку и побеже” (Булгаков 2014: 50). Сарамаго на многим местима изражава сумњу у погледу истинитости јеванђеља. Пишући своје јеванђеље, јеванђелиста у његовом роману наводи имена тројице Јевреја, да би потом констатовао: „Пошто су наведена имена, што је доказ да су та лица која су та имена носила заиста и постојала...” (Saramago 2012: 32), иронично се тако осврћући на фикционалну природу библијских јеванђеља. Осим тога, индикативан је наслов Сарамаговог романа Јеванђеље nо Исусу Христу. Део наслова „по Исусу Христу” обећава нам заправо истиниту причу о Исусовом животу, будући да је она дата по Иcycy, а не, посредно, по Марку, Матеју, Луки и Јовану, чиме се канонска јеванђеља дисквалификују као лажна слика о Исусу. Приповедач се ставља у улогу јеванђелисте, што је јасно сугерисано првим мотоом романа преузетим из Јеванђеља по Луки: „Будући да су многи покушали изложити казивање о догађајима који су се догодили међу нама [...] намислих и ја, испитавши тачно све од почетка, по реду писати теби...” (Лука 1: 1-4). Као други мото романа јавља се Пилатово „Quod scripsi, scripsi”" ${ }^{14}$ из Јеванђеља по Јовану (Јован 19: 22), чиме јеванђелиста потврђује да стоји иза своје верзије приче. У уводном делу који се, не случајно, зове „Блага вест”, улогу јеванђелисте узима и приповедач Пекићевог романа, који говори о свом тексту као о „приповести о Њему”: „Ово је приповест о Њему, Његовом учењу и ученицима [...] Ово је приповест о томе како се рађало Његово Ново царство над царствима" (Рekić 2019: 14). Притом се у уводном делу

${ }^{14}$ „Што писах, писах”. 
пародично имитира библијски родослов и библијски стил: „И би вече, и би јутро. И би свет. Дан први” (исто, 11). Такође, у Времену чуда је апостол Тома онај који доводи у питање библијски текст говорећи како су пророци исувише слаткоречиви и називајући их, иронично, „видовитим друштвом” (исто, 269). Тома размишља о метафорама, апстракцијама и пренесеним значењима, изражавајући притом сумњу према онима који, попут Јуде, пророке схватају тако озбиљно и дословно (исто). Он подсећа Јуду на то да је Исусово страдање и телесно страдање, а „тело које ће се бацакати закуцано за тај пророчки крст неће бити сушта апстракција, поетска метафора једне неутаживе жеђи за спасењем" (исто). Јуда такође машта да напише „истинско јеванђеље” (исто, 341), што је метапоетичка алузија, будући да Пекићев роман и јесте, као што је речено, Јеванђеље по Јуди.

Претходно наведени однос писаца према јеванђеоском тексту отвара и питање статуса текста и књиге у самим романима, тј. питање о вештини тумачења, о односу текста, тумачења и (конструисања) стварности. Соцреалистичка поетика, на коју је критички усмерен Булгаков, покушала je, на пример, да понуди једну визију света коју је желела да прогласи за реалност. Својом фантастиком, сатиром, хумором, роман Мајстор и Маргарита јесте коментар на поетику социјалистичког реализма (Belyk 2012). Сатира је у првој деценији после Октобарске револуције била дозвољена и могла је адресирати појаве у иностранству или у новооуспостављеном систему на домаћем терену (докле год се цео систем није доводио у питање) (Peters 1990: 212-213). Лењин је био расположен и према сатири Мајаковског (исто, 212), а и други писци - као што су Демјан Бедни, Михаил Зошченко, Булгаков, Андреј Платонов - могли су несметано да стварају докле год њихови радови не би били, као што је речено, усмерени на „новоосновани политички систем и његов идеолошки темељ у целини" (исто; према нашем преводу). Међутим, у Стаљиново доба однос према сатири био је оштрији - сатира је надаље, као и читава соцреалистичка књижевност, имала да буде без песимистичких тонова, усмерена искључиво на критику спољних непријатеља, у служби стварања новог совјетског човека (исто, 215). Сатире Мајаковског се више нису помињале, Зошченкове сатире и хумористичне кратке приче биле су критиковане као исувише песимистичне (исто). Још у првом поглављу романа, а у вези са „антирелигозном” поемом Ивана Бездомног о Исусу, Булгаков се подсмева соцреалистичкој поетици (Булгаков 2014: 35). Осим тога, Берлиоз је председник удружења писаца МАССОЛИТ из Грибоједовљевог дома (исто, 84-85), које у роману заступа званичну државну књижевну политику. Булгаков се са највећим могућим подсмехом односи према том 
удружењу - комична су имена која даје писцима удружења: Кормилар Жорж, Павијанов, Богохулски... (исто, 90), као и оне деонице романа у којима Коровјов и Бехемонт исказују тобожње одушевљење домом књижевника у којем „сазрева сијасет талената” (исто, 410), у којем су будући аутори „Дон Кихота, Фауста [...] Мртвих душа" (исто). Задатак писаца социјалистичког реализма био је, дакле, да представе идеализоване јунаке на које би се совјетски грађани могли угледати: „Социјалистичком реализму није одговарало да истражује унутрашње биће књижевних јунака, који су уместо тога имали мотивациону и инспираторску улогу" (Belyk 2012: прво поглавље; према нашем преводу). Јунаци соцреалистичке литературе били би свим срцем посвећени идејама партије, без индивидуалих жеља, скептицизма и песимизма, због чега им је фалило психолошке уверљивости (исто). Булгаков показује да стварност коју су конструисали писци соцреалистичке поетике није, међутим, одговарала оној коју су Московљани живели. Московљани су и те како имали индивидуалних жеља, били заинтересовани за новац, за стамбени простор и друга материјална добра, и то све, делимично, под притиском ниског животног стандарда, о чему можда најбоље говори ненамерно духовито објашњење бифеџије Андреја Фокича да се у Варијетеу, где долази обичан свет, служи јестера „другог степена свежине” (Булгаков 2014: 250) - дакле, покварена храна. Једино приливегованима, попут писаца из МАССОЛИТ-а, нудили су се обиље хране (исто, 87) и комфоран животни простор. Мајстор је крајња супротност и соцреалистичком јунаку и соцреалистичком писцу. Прво, тешко да се он уопште може сматрати главним јунаком романа будући да се појављује само у пет поглавља иако је његово име у наслову. Управо је он, затим, као писац, унео у књижевност забрањену, религиозну или, како би рекао уредник, који је одбио објављивање романа о Пилату, „чудну тему”. Критичари Ариман, Латунски и Лаврович започињу беспоштедно разрачунавање са Мајстором, називајући његову књигу „апологијом Исуса Христа” (исто, 181), а њега „ратоборним поборником староверства” (исто, 182).

Јуда у Пекићевом роману такође жели да његове визије и тумачења постану стварност и предузимљиво дёла̄ да би ту жељу остварио. Њега раскринкава Филип, чији ће глас касније, попут гласа сопствене савести, Јуда непрекидно чути (Pekić 2019: 278). Филип му говори да је „проклети лажов" (исто, 273) незаинтересован за Христа и за спасење света, већ само за то да испуњењем пророчанстава његова вера добије доказа и постане опипљива (исто, 273-275). Оно што Филип хоће да сугерише јесте да вери, правој вери, ништа такво није потребно - она се зове вером баш зато што 
не зависи од спољних фактора, што је сва „унутрашња”, што је у реду да трпи „рупе, пукотине, огреботине” (исто, 274), тј. да буде несавршена. Не само да дословно тумачи речи пророка, већ Јуда јасно манипулише туђим речима - он ће слагати Христа да му се Адонај јавио и рекао да ће се о свему побринути, пустивши га да верује како то значи да ће му Бог помоћи при самртним мукама (исто, 289-290). Јуда зна да Адонај није обећао да ће тако помоћи Христу, па своју лаж оправдава говорећи да се оно што је Адонај заправо рекао може протумачити и онако како управо он, Јуда, жели: „Не, Јудо, ти не лажеш, ти само на свој начин схватам једну божанску поруку" (исто, 290; наше подвлачење).

Сарамагов Ирод пак држи се Кюиге пророка Михеја, открива у њој претњу и зато убија сву витлејемску децу (Saramago 2012: 85-87 и 94). У књизи је Ирод описан као параноидни владар, мучен ноћним морама у којима га, изгледа, редовно посећује пророк Михеј (исто, 85). Тако једне ноћи Михеј изговара чувене речи: да ће из Витлејема изаћи нови израиљски краљ (исто). ${ }^{15}$ Оптерећен заверама на сопственом двору, у неурастеничком страху да ће му бити одузет престо, Ирод, умногоме попут Пекићевог Јуде, своди Михејину појаву и речи из сна на једно једино значење; тумачи их дословно - као упозорење да се будући краљ већ родио, чему се јеванђелиста јасно изругује: „Одлази, све је јасно, књига је најављивала будуће рођење, ништа више, док му се Михејин дух приказао у сну да га упозори да се то рођење већ догодило. Све је јасно да не може бити јасније, баш као што су јасне речи свих других пророка, чак $u$ кад их ломе протумачимо (исто, 87 ; наше подвлачење), чиме се и у овој књизи отвара помињани проблем тумачења текста од кога онда зависи предузимање акције и, у ширем, уређење света, а Ироду је, као и Јуди, у њиховом крајњем егоизму, све јасно. Ирод убија свештеника који је дошао да му прочита Кюигу пророка Михеја (исто), а за саму књигу се каже да после тога нестаје, на шта се јеванђелиста иронично осврће речима: „замислите какав би то био губитак да је то био једини примерак” (исто). Код Сарамага се књиге не враћају из „пете димензије”, али као и у Мајстору u Маргарити, оне нестају (као што, уосталом, „нестају” и људи) ${ }^{16}$ када треба да се затре идеја која се не допада немаштовитим тумачима.

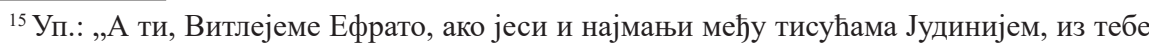
ће ми изаћи који ће бити Господар у Израиљу, којему су изласци од почетка, од вјечнијех времена" (Мих. 5: 2). Види такође: Мат. 2: 6, Јован 7: 42.

${ }^{16}$ Стјопа Лиходејев, директор Варијетеа, нестаје из стана, тј. Воланд га шаље у удаљену Јалту (Булгаков 2014: 139-140), што призива историјски контекст изненадних нестајања и хапшења онога времена, а индикативно је и што Бездомни већ у првом поглављу романа помиње Соловке (исто, 39) као радни логор. Тако ће се и у Пекићевом роману говорити о 
И соцреализам и Јуда и Ирод критиковани су овде као они који злоупотребљавају текст за сопствена нахођења. И још више - Јуда и Ирод критиковани су као ограничени тумачи. Не тумаче текст лоше само Јуда и Ирод, тако га тумаче - сада већ очигледно у складу са својом идеолошком позицијом - и Булгаковљеви критичари Латунски и Ариман, мучећи Мајстора свакојаким оптужбама (Булгаков 2014: 181-182). У Булгаковљевом роману се сам Јешуа жали како људи не разумеју његове речи и како почиње да се боји „да ће та збрка потрајати још дуго” (исто, 50) чиме се опет алудира на хришћанске текстове - у основи будућег хришћанства, сугерише се, стоје погрешна тумачења Христа и његових речи. Осим тога, Јешуино позивање на „рушење храма старе вере” људи су - као Јуда и Ирод своје текстове - разумели дословно, наиме - као конкретно, физичко рушење храма (исто). Мајстор ће спалити свој роман под притиском критичара (исто, 185), као што ће се и Книзи пророка Михеја изгубити сваки траг након што је Ирод из ње ишчитао оно што је желео (Saramago 2012: 87).

За разлику од писаца романа којима се бавимо - Булгакова, Пекића и Сарамага - који су крајње сумњичави према (јеванђеоском) тексту, који га иронизују и пародирају, па чак и одбацују, показујући могућност релативизације онога што се сматра утврђеном истином, указујући на начине на које моћ конструише истину и стварност, јунаци њихових романа - попут критичара Латунског и Аримана, Јуде и Ирода - јесу они са симплификованим односом према тексту и са неплеменитим циљевима који усмеравају њихова тумачења.

Међутим, да се понека истина о свету ипак може рећи, најбоље сведочи роман Мајстор и Маргарита. Булгаковљев роман доноси идеју о томе да истину о свету може да понуди добра уметност. Уметност је код Булгакова наднаравног карактера - Мајсторев роман први пут приповеда Воланд, његов садржај се затим јавља Бездомном у сну, а роман о Пилату читао је и сам Јешуа. Уметност је магичног карактера, она повезује различите просторно-временске равни, обогађује реалност фантастиком и, осим тога, бесмртна је - ако се тако може протумачити Воландова чувена констатација „Рукописи не горе!” (Булгаков 2014: 339) и Бехемонтов узвик „Достојевски је бесмртан!” (исто, 411). Уметност припада, дакле, магичној „петој димезији”, у којој се може ширити простор и заустављати време. Она једина може да зна истину о прошлости и садашњости, баш као што

војницима који хапсе ноћу и изненадно (Pekić 2019: 206), а биће речи и о прокураторовим логориштима изван Јерусалима (исто, 209), што су све алузије на поменути историјски контекст (Срећковић 1992: 1731-1732). 
Мајстор у свом роману зна шта се догодило давног Јерусалимског дана иако је његов роман настао вековима касније. Добра уметност је, дакле, свемогућа. Мишљења смо да Булгакова, Пекића и Сарамага не интересују на првом месту крајња деконструкција знања̄, истина̄ и стварностй. Фокус је на отпору који је усмерен против онога нехуманог и неплеменитог, ускогрудног, ограниченог и репресивног - критика, сумњичавост и деконструкција су стога у служби таквог отпора. Сарамаго је, истакли смо, и у савременом глобалистичком свету препознавао репресивне, тоталитарне тенденције. Остаје да видимо како ће се у таквом свету аутори надаље односити према библијском тексту, како ће се он призивати и ресемантизовати, какви ће се проблеми притом отварати и каква ће се, можда, „нова јеванђеља” у будућности написати. ${ }^{17}$

\section{ИЗВОРИ}

Библија или Свето писмо Старога и Новога завјета (2017), прев. Стари завјет Ђура Даничић, Нови завјет Комисија Светог архијерејског синода СПЦ, Београд: Библијско друштво Србије.

Булгаков 2014: Михаил Булгаков, Мајстор и Маргарита, прев. Злата Коцић, Београд: Завод за уџбенике и наставна средства.

Пекић 1987: Борислав Пекић, интервју са Бором Кривокапићем, $H И Н$, 13. и 20. септембар 1987. [Online]. Доступно на: www.borislavpekic. $\mathrm{com} / \mathrm{p} / \mathrm{bio} . \mathrm{html}$ [приступљено: 5. новембра 2021].

Пекић 1989: Борислав Пекић, интервју са Весном Рогановић, Борба, 28. септембар 1989. [Online]. Доступно на: www.borislavpekic.com/p/bio.html [приступљено: 5. новембра 2021].

Dostojevski 2015: Fjodor Mihailovič Dostojevski, Braća Karamazovi I i II, prev. Veljko Lukić i Jakša Kušan, Beograd: Book.

Kami 2019: Alber Kami, Pad, prev. Vuk Bijelić, Beograd: Kontrast.

Pekić 1984: Borislav Pekić, „Nisam Japanac izgubljen u džungli”- (III nastavak), intervju vodio A. Arsenijević, Vidici, Beograd. [Online]. Доступ-

${ }^{17}$ Поменућемо на овом месту Достојевског, који је први употребио јеванђеоски предложак да би се супротставио Инквизиторевој тоталитарној аргументацији (Dostojevski 2015 (I): 282-304) у свом последњем роману Браћа Карамазови (1879/1880). Линија употребе јеванђеоског предлошка у том контексту наставља се са ауторима чије смо романе анализирали. Албер Ками је, такође, 1956. године написао роман Пад, у коме успоставља мноштво интертекстуалних веза са Достојевским. И Ками у свом роману полемише са јеванђеоским предлошком, концентришући се, попут Сарамага, на страдање витлејемске деце (Kami 2019: 75). Христова фигура је у овом случају поново супротстављена Кламансовом нарцизму и његовим тоталитарним становиштима која наличе Инквизиторевим. 
но на: http://www.borislavpekic.com/2008/03/vreme-rei-xd-deo.html [приступљено: 5. новембра 2021].

Pekić 2019: Borislav Pekić, Vreme čuda, Beograd: Laguna.

Saramago 2002: José Saramago, „A Life of Resistance”, documentary by Julian Evans, UK: BBC Four. [Online]. Доступно на: https://www.youtube. com/watch?v=jxy_Ax71JUI [приступљено: 5. новембра 2021].

Saramago 2012: Žoze Saramago, Jevanđelje po Isusu Hristu, prev. Dejan Tiago Stanković, Beograd: Laguna.

Saramago 2014: Žoze Saramago, Kain, prev. Jasmina Nešković, Beograd: Laguna.

\section{ЛИТЕРАТУРА}

Ахметагић 2006: Јасмина Ахметагић, Антропопеја: библијски подтекст Пекићеве прозе, Београд: Драслар.

Деветаковић 2004: Наташа Деветаковић, „Мајстор и Маргарита Михаила Булгакова", Зборник Матице српске за славистику, књ. 65/66, 163-217.

Драгутиновић 2010: Предраг Драгутиновић, Основе новозаветне науке I: Увод у Нови завет, Београд: Православни богословски факултет Универзитета, Институт за теолошка истраживања.

Јерков 1992а: Александар Јерков, „Постмодерно доба српске прозе”, предговор у: Антологија српске прозе постмодерног доба, Београд: СКЗ, 7-61.

Јерков 1992b: Александар Јерков, „Пекићева цинична интертекстуалност”, Книжевност, књ. 92-93, год. 47, бр. 11-12, 1703-1711.

Пијановић 1991: Петар Пијановић, Поетика романа Борислава Пекића, Београд: Просвета.

Радуловић 2016: Немања Радуловић, „Време чуда и неке гностичке паралеле", Philologia Mediana, год. 8, бр. 8, 61-70. [Online]. Доступно на: https://philologiamediana.com/ [приступљено: 8. новембра 2021].

Срећковић 1992: Милутин Срећковић, „Ноmo Novus у пародијском светлу историје”, Книжевност, књ. 92-93, год. 47, бр. 11-12, 1724-1734.

Belyk 2012: Kristina Belyk, „The Master and Margarita: Deconstructing Social Realism", BrightONLINE Student Literary Journal, Issue 3. [Online]. Доступно на: http://arts.brighton.ac.uk/ [приступљено: 10. новембра 2021].

Flaker 1993: Aleksandar Flaker, Bulgakovljev Majstor i Margarita", поговор у: Majstor i Margarita, prev. Vida Flaker, Rijeka: ANDROMEDA, 423-431. [Online]. Доступно на: https://www.academia.edu/ [приступљено: 7. новембра 2021]. 
Horsley 2006: Richard A Horsley, „Early Christian Movements: Jesus Movements and the Renewal of Israel", HTS Teologiese Studies, Vol. 62, No. 4, Cape Town: AOSIS OpenJournals, 1201-1225. [Online]. Доступно на: https://hts.org.za/ [приступљено: 7. новембра 2021].

Peters 1990: Jochen-Urlich Peters, „Satire under Stalinism: Zoshchenko's Golubaya Kniga and M. Bulgakov's Master i Margarita", The Culture of the Stalin Period (ed. Hans Gunther), London: Palgrave Macmillan, 210-226.

Rollason 2004: Christopher Rollason, „Globalisation and particularism in the work of José Saramago: the symbolism of the shopping-mall in A Caverna", Global Neo-Imperialism and National Resistance: Approaches from Postcolonial Studies (eds. Belén Martín Lucas and Ana Bringas López), Vigo: Servicio de Publicacións da Universidade de Vigo, 207-216. Доступно на: https://www.academia.edu/ [приступљено: 5. новембра 2021].

Rollason 2006: Christopher Rollason, „How Totalitarianism Begins at Home: Saramago and Orwell", In Dialogue with Saramago: Essays in Comparative Literature (eds. Mark Sabine and Adriana Alves de Paula Martins), Manchester: University of Manchester, 105-120. [Online]. Доступно на: https://www.academia.edu/ [приступљено: 5. новембра 2021].

Salzani C. - Kristof K. P. Vanhoutte 2018: Carlo Salzani and Kristof K. P. Vanhoutte (eds.), Saramago's Philosophical Heritage, London: Palgrave Macmillan [Online]. Доступно на: https://www.academia.edu/ [приступљено: 5. новембра 2021].

Aleksandra N. Petrović

NEW GOSPELS AND RESISTANCE TO REPRESSION: THE MASTER AND MARGARITA BY M. BULGAKOV, TIME OF MIRACLES BY B. PEKIĆ AND THE GOSPEL ACCORDING TO JESUS CHRIST BY J. SARAMAGO

\section{Summary}

The study deals with the comparative analysis of The Master and Margarita by M. Bulgakov, Time of Miracles by B. Pekić, and The Gospel According to Jesus Christ by José Saramago in reference to their views on the evangelical model. The novels refer to the evangelical text in two conflicting ways - firstly, they follow the evangelical text since they, too, originate from the historical context of resisting repression, and at the same time they proclaim human existential values. On the other hand, the authors shy away from the evangelical text, reject it or ridicule it, through the use of satire, parody, and irony. The 
authors, unlike the heroes of their respective novels - express doubts about the text and the promises that it offers, further showing suspicion towards contemporary ideological narratives. Having now become evangelists, the authors in this way write their own heretic gospels of the twentieth century.

Key words: gospel, twentieth century, repression, text, reality 